\title{
Effects of high intensity interval training on exercise capacity in people with chronic pulmonary conditions: a narrative review
}

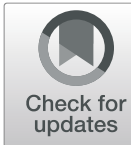

Abbey Sawyer ${ }^{1,2,3}$, Vinicius Cavalheri ${ }^{1,3,4}$ and Kylie Hill ${ }^{1,3^{*}}$

\begin{abstract}
Background: Exercise training is important in the management of adults with chronic pulmonary conditions. However, achieving high intensity exercise may be challenging for this clinical population. There has been clinical interest in applying interval-based training as a strategy to optimise the load that can be tolerated during exercise training. Evidence for such an approach is limited in most chronic pulmonary populations.

Main body: In this narrative review, we provide an appraisal of studies investigating whole-body high intensity interval training (HIIT) in adults with chronic obstructive pulmonary disease (COPD). This is the first review to also include studies investigating HIIT in people with conditions other than COPD. Studies undertaken in adults with a chronic pulmonary condition were reviewed when participants were randomised to receive; (i) HIIT or no exercise or, (ii) HIIT or moderate intensity continuous exercise. Data were extracted on peak rate of oxygen uptake $\left(\mathrm{VO}_{2 \text { peak }}\right.$; 'cardiorespiratory fitness') and maximal work rate ( $\mathrm{W}_{\text {maxi }}$ 'exercise capacity').

In people with COPD, two studies demonstrated between-group differences favouring HIIT compared with no exercise. There appears to be no advantage for HIIT compared to continuous exercise on these outcomes. In people with cystic fibrosis (CF), no studies have compared HIIT to no exercise and the two studies that compared HIIT to continuous exercise reported similar benefits. In people prior to resection for non-small cell lung cancer, one study demonstrated a between-group difference in favour of HIIT compared with no exercise on $\mathrm{VO}_{2 \text { peak. }}$. In people with asthma, one study demonstrated a between-group difference in favour of HIIT compared with no exercise on $\mathrm{VO}_{2 \text { peak }}$ and one that compared HIIT to continuous exercise reported similar benefits. No studies were identified non-CF bronchiectasis or interstitial lung diseases.
\end{abstract}

Conclusions: High intensity interval training increases cardiorespiratory fitness and exercise capacity when compared with no exercise and produces a similar magnitude of change as continuous exercise in people with COPD. There is a paucity of studies exploring the effects of HIIT in other chronic pulmonary conditions.

Keywords: Adults, Chronic pulmonary disease, Exercise, High intensity interval training

\footnotetext{
* Correspondence: K.Hill@curtin.edu.au

${ }^{1}$ School of Physiotherapy and Exercise Science, Faculty of Health Science,

Curtin University, GPO Box U1987, Perth, WA 6845, Australia

${ }^{3}$ Institute for Respiratory Health, Perth, WA, Australia

Full list of author information is available at the end of the article
}

\section{$\triangle B M C$}

(c) The Author(s). 2020 Open Access This article is licensed under a Creative Commons Attribution 4.0 International License, which permits use, sharing, adaptation, distribution and reproduction in any medium or format, as long as you give appropriate credit to the original author(s) and the source, provide a link to the Creative Commons licence, and indicate if changes were made. The images or other third party material in this article are included in the article's Creative Commons licence, unless indicated otherwise in a credit line to the material. If material is not included in the article's Creative Commons licence and your intended use is not permitted by statutory regulation or exceeds the permitted use, you will need to obtain permission directly from the copyright holder. To view a copy of this licence, visit http://creativecommons.org/licenses/by/4.0/ The Creative Commons Public Domain Dedication waiver (http://creativecommons.org/publicdomain/zero/1.0/) applies to the data made available in this article, unless otherwise stated in a credit line to the data. 


\section{Background}

Exercise training is important in the management of adults with chronic pulmonary conditions. Systematic reviews, undertaken in clinical populations, such as adults with chronic obstructive pulmonary disease (COPD) [1, $2]$, cystic fibrosis (CF) [3, 4], non-CF bronchiectasis, interstitial lung diseases (ILDs) [5-7], asthma [8], and nonsmall cell lung cancer (NSCLC) [9-11] have shown that exercise training is effective at increasing components of cardiorespiratory fitness (i.e. the peak rate of oxygen uptake; $\mathrm{VO}_{2 \text { peak }}$ ) and exercise capacity (i.e. the maximal work rate; $\left.W_{\max }\right)$. Additionally, exercise training has been demonstrated to reduce the severity of symptoms experienced during daily life such as dyspnoea and fatigue and improve health-related quality of life [12]. In the general population, exercising at moderate to high intensity is recommended to optimise the magnitude of improvement in cardiorespiratory fitness and exercise capacity [13]. Consistent with these data, studies of people with COPD suggest that, in contrast with low intensity exercise, high intensity exercise training may be advantageous in terms of eliciting a physiological training response [14-17]. These data are in keeping with the overload principle, which states that in order to improve cardiorespiratory fitness and/or exercise capacity, exercise training must be undertaken at an intensity that is greater than the load borne during daily life [18, 19].

Regarding the mechanisms underpinning the improvements in cardiorespiratory fitness and/or exercise capacity, gains are not mediated through improvements in lung function [20-22]. In fact, some of the earliest work done in the area of exercise training for people with COPD [23] was met with scepticism as the gains in exercise capacity were demonstrated without any change in forced expiratory volume in 1 second $\left(\mathrm{FEV}_{1}\right)$. In the mid-1990s, seminal work demonstrated that the changes in exercise capacity were mediated, at least in part, by improved condition of the peripheral muscles, largely vastus lateralis [24]. For example, cycle ergometry training resulted in increased activity of two oxidative enzymes, citrate synthase (CS) and 3-hydroxyacyl-CoA dehydrogenase (HADH) (from $22 \pm 4$ to $26 \pm 4 \mu \mathrm{mol} / \mathrm{min} / \mathrm{g}$ muscle for CS, $p<0.05$, and from $6 \pm 3$ to $8 \pm 3 \mu \mathrm{mol} / \mathrm{min} / \mathrm{g}$ for $\mathrm{HADH}, p<0.01$ ) [24]. In populations characterised by chronic pulmonary conditions, high intensity exercise training may also optimise cardiovascular health [25-27]. Although these data exist predominantly for people with COPD, guidelines regarding the prescription of exercise training for people with other chronic pulmonary conditions often recommend training at moderate intensity or higher [4, 28, 29]. However, achieving high intensity exercise may be challenging for this clinical population. The reasons for this are multifactorial. First, people with moderate to severe disease are likely to demonstrate ventilatory limitation $[14,30]$, coupled with worsening pulmonary mechanics during exercise [15], both of which serve to constrain the intensity that can achieved before the onset of intolerable dyspnoea. Second, some people with chronic pulmonary conditions, who do not qualify for long term oxygen therapy, demonstrate a marked reduction in arterial oxygen saturation on exertion. This is due largely to ventilation and perfusion mismatch (V/Q mismatch) and is generally more pronounced in people with severe pulmonary disease [31]. In some clinical populations, such as those with COPD who demonstrate transient exertional desaturation despite being normoxaemic at rest, recent data suggests that, when compared with gains derived from training on room air, the use of supplemental oxygen offers no additional benefit [32]. In other populations, such as those with ILDs, even high dose supplemental oxygen may not be able to prevent marked desaturation [33, 34]. In the presence of transient exertional desaturation, clinicians may choose to reduce the exercise intensity, which compromises the training dose achieved. Third, many people with chronic pulmonary disease, particularly those who are older, have co-morbid conditions which contributes to the difficulty achieving high intensity exercise. These conditions may include osteoarthritis [35], feelings of anxiety and depression [36] or obesity [37]. Given these challenges, there has been clinical interest in applying interval-based training as a strategy to optimise the load that can be tolerated during exercise training [38-40].

\section{High intensity interval training}

Intermittent or interval training approaches are characterised by repeated cycles of 'work' interrupted by 'rest' $[41,42]$. The main difference between these approaches is that, for intermittent training, the patient chooses the work and rest times based on the tolerability of their symptoms, whereas for interval training, the work to rest ratios are prescribed by the therapist. Both approaches are likely to be especially advantageous in people with severe pulmonary disease, who due to intolerable symptoms, may be unable to engage in continuous exercise at an intensity sufficient to induce a training adaptation. In this population, punctuating work periods with rest periods provides intermittent relief from the ventilatory demand associated with exercise, which serves to reduce the work of breathing and dyspnoea. This in turn offers the opportunity to optimise the training intensity that can be borne during the next work period [30]. Given this advantage, the work intervals are often performed at higher intensities than could be tolerated with continuous training. Repeating this work to rest cycle allows the prolonged exposure of the peripheral muscles to high intensity exercise; a stimulus necessary to elicit physiological adaptions [43]. In the literature, interval based training has been described more often than intermittent 
training because in contrast with an intermittent approach, interval based training is highly standardised, reproducible and the parameters can be manipulated by the therapist. As the work periods are performed at high intensities, this type of training is often described as high intensity interval training (HIIT).

Studies that were reviewed in this paper needed to meet our definition of HIIT; specifically the work intervals used during the training program were conducted at an intensity equivalent to $\geq 80 \%$ of maximum (maximum work rate / peak power / $\mathrm{VO}_{2 \text { peak }}$ or maximum heart rate) determined during a baseline incremental / ramp laboratorybased cycle ergometry test in which work rates progressively increased each minute [13]. As the optimal work to rest ratio for HIIT is unknown, no criteria for inclusion in this review were set for this parameter. Nevertheless, it is worth noting that in order to maximise the stimulus needed to improve the oxidative capacity of the peripheral muscles, a ratio that maximises workload during the work periods and minimises the duration of the rest intervals would seem ideal. In this way, exposure of the peripheral muscles to the milieu of by-products associated with anaerobic metabolism could be maximised; a stimulus necessary to promote mitochondrial biogenesis [43, 44].

One study in people with COPD compared fluctuating work to rest intervals of 4 minutes of work to 4 minutes of rest, using a sinusoidal wave form, with the use of a faster fluctuations, characterised by 1 minute of work to 1 minute of rest. Compared with the slower fluctuations, faster fluctuations between work and rest allowed people with COPD to achieve supramaximal work rates (i.e. 120\% of their maximal work rate $\left[\mathrm{W}_{\max }\right]$ ), with considerably less ventilatory load [43]. This suggests that faster fluctuations between work and rest intervals may offer advantage over slower fluctuations for improvements in muscle adaption, cardiorespiratory fitness and exercise capacity.

Another advantage of HIT is its efficiency for producing training-related gains. Specifically, in sedentary healthy adults as well as in athletes, this type of exercise produces physiological evidence of a training effect over a period as little as 2 weeks [44]. In healthy young adults $(n=8$, mean $\pm \mathrm{SD}$, aged $22 \pm 1$ years, peak rate of oxygen uptake $\left[\mathrm{VO}_{2 \text { peak }}\right] 45 \pm 3 \mathrm{~mL} / \mathrm{kg} / \mathrm{min}$ ), as few as six sessions of cycling-based HIIT over 2 weeks has been shown to produce a significant improvement in endurance capacity (12\% change from baseline), and changes in the peripheral skeletal muscles (i.e. vastus lateralis) which were indicative of increased oxidative capacity. These changes were over and above any seen in a control group [45]. However, it is important to note that this study did not show improvements in cardiorespiratory fitness $\left(\mathrm{VO}_{2 \text { peak }}\right)$, despite improvement in other exercise outcomes.

Importantly, a HIIT protocol may also be more time efficient than a continuous protocol [46]. That is, a randomised controlled trial (RCT) undertaken in sedentary males $(n=25$, aged $27 \pm 8$ years, body mass index [BMI] $26 \pm 6 \mathrm{~kg} / \mathrm{m}^{2}$ ) allocated participants to one of three groups: (i) HIIT $(n=9)$ which comprised three bursts of 20 s cycle sprints interspersed with 2 minute periods of low intensity cycling, completed three times a week for 12 weeks, (ii) continuous cycling $(n=10)$ which comprised 45 min of cycling at $\sim 70 \%$ maximal heart rate, completed three times a week for 12 weeks or, (iii) a control group $(n=6)$ which did not receive any cycling training. This RCT demonstrated that, compared with the control group, participants in both of the exercise groups increased their $\mathrm{W}_{\max }$ (mean difference [MD] $62 \mathrm{~W}, 95 \% \mathrm{CI}$ 4 to 120 [HIIT] and MD 58 W, 95\% CI 7 to 109 [continuous cycling]). However, despite the substantially shorter training time in the HIIT group compared with the continuous exercise training group (30 min a week compared to $135 \mathrm{~min}$ a week with workloads titrated according to rate of perceived exertion), the $\mathrm{VO}_{2 \text { peak }}$ on completion of the exercise training period was similar between groups (MD $-2 \mathrm{~mL} / \mathrm{kg} / \mathrm{min}, 95 \% \mathrm{CI}-10$ to 6) [46]. The strong physiological rationale for HIIT coupled with data demonstrating both effectiveness and efficiency in sedentary populations makes this approach an attractive option for use in adults with a chronic pulmonary condition. Further, in contrast with other approaches that aim to optimise the training load borne by the peripheral muscles by reducing the ventilatory load associated with exercise (e.g. proportional assist ventilation, heliox), HIIT does not require extra equipment and is an inexpensive option that can be incorporated into daily life.

Recent work has indicated that HIIT is used in clinical practice. That is, our group recently conducted a survey of Australian and New Zealand CF centres to determine, in part, the extent and scope of exercise training in people with CF [47]. The results of this survey found that HIIT is commonly prescribed by therapists despite limited research to support this type of training [47]. In addition, people with interstitial lung diseases (ILDs) are often prescribed interval-based training as a 'lead in' phase within studies investigating the effects pulmonary rehabilitation in people with ILDs $[48,49]$.

The aim of this narrative review was to synthesise the data that have reported the effects of land-based wholebody HIT on cardiorespiratory fitness $\left(\mathrm{VO}_{2 \text { peak }}\right)$ and/or exercise capacity $\left(\mathrm{W}_{\max }\right)$ in adults living with chronic pulmonary conditions, including people with COPD, CF, non-CF bronchiectasis, asthma, ILDs and NSCLC. This narrative review will provide an update of studies investigating whole-body HIIT in adults with COPD, and will be the first study to review studies in other chronic pulmonary conditions. As HIIT is most often undertaken on a cycle ergometer in studies, outcomes reported on in this review were selected based on the principle of 
task specificity [50], and comprised $\mathrm{VO}_{2 \text { peak }}$ and $\mathrm{W}_{\max }$ measured during a cycle-based cardiopulmonary exercise test. Where possible, for each condition, studies that have explored the effectiveness of HIIT compared to usual care (i.e. no exercise) are presented separately to those that have compared the effects of HIIT with continuous exercise training. This is the first review to take this approach.

\section{Chronic obstructive pulmonary disease}

Two studies have compared the use of HIIT, embedded within a 12-week pulmonary rehabilitation program, to no exercise (i.e. the comparison is a control group with no exercise or pulmonary rehabilitation program), on measures of exercise capacity in people with COPD [51, 52]. In one study, the HIIT intervention commenced with 'work' intervals at $80 \%$ of the $\mathrm{W}_{\max }$, interspersed with an active recovery $\left(40 \% \mathrm{~W}_{\max }\right)$, for 30 and $90 \mathrm{~s}$, respectively, for $20 \mathrm{~min}$, repeated twice per week [51]. When compared with the usual care group ( $n=15$, aged $80 \pm 6$ years, $\mathrm{FEV}_{1} 60 \pm 15 \%$ predicted), those who undertook HIIT ( $n=14$, aged $80 \pm 8$ years, $\mathrm{FEV}_{1} 47 \pm 18 \%$ predicted) demonstrated greater changes in $\mathrm{VO}_{2 \text { peak }}$ (MD $4 \mathrm{~mL} / \mathrm{kg} / \mathrm{min}, 95 \% \mathrm{CI} 1$ to 7) [51]. In the other study, the HIIT intervention comprised a 45 min session of $30 \mathrm{~s}$ intervals of $130 \pm 18 \% \mathrm{~W}_{\max }$ interspersed with $30 \mathrm{~s}$ rest periods, performed thrice weekly [52]. When compared with the usual care group $(n=43$, aged $67 \pm 8$ years, $\mathrm{FEV}_{1} 45 \pm 19 \%$ predicted), those who undertook HIIT ( $n=85$, aged $65 \pm 8$ years, $\mathrm{FEV}_{1} 49 \pm 19 \%$ predicted) demonstrated greater changes in measures of cardiorespiratory fitness $\left(\mathrm{VO}_{2 \text { peak }} ; \mathrm{MD} 2 \mathrm{~mL} / \mathrm{kg} / \mathrm{min}, 95 \%\right.$ CI 1 to 4 ) and exercise capacity ( $\mathrm{W}_{\max }$; MD $16 \mathrm{~W}, 95 \% \mathrm{CI}$ 5 to 27) [52]. Nevertheless, as both studies explored the effect of HIIT provided within a pulmonary rehabilitation program, which included resistance exercises and education, the gains in cardiorespiratory fitness and/or exercise capacity cannot be directly attributed solely to the HIIT.

Several studies have compared the effect of HIIT with continuous training in people with COPD (Table 1). Data from these trials have been meta-analysed in previous reviews $[18,39,62]$. However, we have found a further two trials since a previous comprehensive review and update $[39,62]$ that compared the effect of HIIT with continuous exercise training on measures of exercise capacity in people with COPD $[60,61]$. The findings of the previous comprehensive review demonstrated comparable effects of the two modes of exercise training on measures of cardiorespiratory fitness $\left(\mathrm{VO}_{2 \text { peak }} ; \mathrm{MD} 0.04 \mathrm{~L} / \mathrm{min}, 95 \% \mathrm{CI}\right.$ 0.13 to 0.05 ) and exercise capacity ( $\mathrm{W}_{\max } ; \mathrm{MD} 1 \mathrm{~W}, 95 \%$ $\mathrm{CI}-1$ to 3 ) [39]. Of the 10 studies that have compared HIIT with continuous training, three appeared to be of moderate quality $[55,57,60]$, whereas the remaining seven studies were of fair to poor quality $[30,53,54,56,58,59]$. With the addition of the two new studies, the summary effect statistic suggests that, for both outcomes, there was no clear evidence for benefit of one form of exercise over the other (Figs. 1 and 2) [81]. Of note, this result did not differ when studies were grouped according to whether or not the total amount of work between the HIIT group and a continuous group was matched [39], or when a random effects model was used. The authors acknowledge that the updated meta-analysis was not undertaken following a systematic review of the literature, and so may introduce bias to the estimate.

\section{Cystic fibrosis}

Although earlier work suggests that HIIT is feasible in people with CF [38, 63, 64], including those who are characterised by severe expiratory airflow obstruction [38], to date, there are no studies that have compared the effects of HIIT, to no exercise, in this population. Only two studies have compared HIIT with continuous exercise (Table 2). In one study $(n=23)$, where possible, participants completed a continuous training program on a treadmill (aged $26 \pm 10$ years, $\mathrm{FEV}_{1} 32 \pm 4 \%$ predicted) ( 45 min of exercise at 60 to $70 \% \mathrm{VO}_{2 \text { peak }}$, five times per week for 6 weeks) and were only allocated to the HIIT group (aged $26 \pm 8$ years, $\mathrm{FEV}_{1} 26 \pm 8 \%$ predicted) if they were unable to tolerate continuous training. The HIIT program comprised $30 \mathrm{~s}$ of walking at the individuals comfortable continuous walking speed (between 3 and $4 \mathrm{~km} / \mathrm{h}$ ) at $50 \%$ of the grade achieved during a steep ramp test on a treadmill (modified Balke-protocol) interspersed with $60 \mathrm{~s}$ of 'rest' (walking at $0 \%$ treadmill inclination). This work to rest ratio was repeated 10 times. On completion of the training program, both groups improved their $\mathrm{VO}_{2 \text { peak }}$ ( $21 \pm 4$ to $23 \pm 7 \mathrm{~mL} / \mathrm{kg} / \mathrm{min}$ in the HIIT group and $21 \pm 7$ to $25 \pm 7 \mathrm{~mL} / \mathrm{kg} / \mathrm{min}$ in the continuous exercise training group; difference in $\mathrm{VO}_{2 \text { peak }}$ between groups was $2 \mathrm{~mL} /$ $\mathrm{kg} / \mathrm{min}$ [ $95 \% \mathrm{CI}-5$ to 3]). Participants in the HIIT group reported the program to be 'motivating and less strenuous' than their previous experience with constant moderate intensity exercise. These results must be interpreted with caution because in this study, group allocation was not decided through a process of randomisation [38]. In addition, while the authors refer to the intervention as HIIT, the equivalent $\mathrm{VO}_{2 \text { peak }}$ and $\mathrm{W}_{\max }$ achieved during the 'work; intervals is not described. However, in comparison to previously-mentioned studies in COPD [57, 58], $50 \%$ of the intensity achieved on a steep ramp test is equivalent to $\sim 90 \%$ of maximum work rate achieved during traditional exercise protocols.

To our knowledge, only one RCT (available as a conference abstract only) has compared HIIT to moderate intensity continuous exercise in adults with CF $(n=24$, age and $\mathrm{FEV}_{1}$ not reported) [65]. In this study, participants were randomised to 12 weeks of HIIT $(n=12)$, or continuous exercise $(n=12)$. The training programs 
Table 1 Description of high intensity interval training compared to continuous exercise training studies in people with chronic obstructive pulmonary disease

\begin{tabular}{|c|c|c|c|c|c|}
\hline & Study & $\begin{array}{l}\text { Type of exercise } \\
\text { and population }\end{array}$ & Interval exercise & Continuous exercise & Frequency \\
\hline \multirow[t]{8}{*}{ Previous review [39] } & $\begin{array}{l}{ }^{\mathrm{a} A r n a d o t t i r}[53] \\
n=60 \\
2007\end{array}$ & $\begin{array}{l}\text { Cycling in people } \\
\text { with COPD }\end{array}$ & $\begin{array}{l}\geq 80 \% \text { peak power, } \\
\text { followed by } 30 \text { to } \\
40 \% \text { peak power } \\
\text { Duration: } 39 \text { min } \\
\text { (intervals of } 3 \text { min: } \\
3 \text { min) }\end{array}$ & $\begin{array}{l}\geq 65 \% \text { peak power } \\
\text { Duration: } 39 \mathrm{~min}\end{array}$ & $\begin{array}{l}2 \times \text { per week } \\
\text { for } 16 \text { weeks }\end{array}$ \\
\hline & $\begin{array}{l}\text { Coppoolse [54] } \\
n=21 \\
1999\end{array}$ & $\begin{array}{l}\text { Cycling in people } \\
\text { with COPD }\end{array}$ & $\begin{array}{l}90 \% \text { peak power } \\
\text { interspersed with } \\
45 \% \text { peak power, } \\
\text { plus continuous } \\
\text { cycling at } 60 \% \\
\text { Duration: } 30 \text { min } \\
\text { (intervals of } 1 \text { min: } \\
2 \text { min) }\end{array}$ & $\begin{array}{l}60 \% \text { peak power } \\
\text { Duration: } 30 \text { min }\end{array}$ & $\begin{array}{l}5 \times \text { per week } \\
\text { for } 8 \text { weeks }\end{array}$ \\
\hline & $\begin{array}{l}\text { Mador [55] } \\
n=41 \\
2009\end{array}$ & $\begin{array}{l}\text { Cycling or treadmill } \\
\text { in people with COPD }\end{array}$ & $\begin{array}{l}150 \% \text { of continuous } \\
\text { exercise target } \\
\text { interspersed with } 75 \% \\
\text { of target } \\
\text { Duration: } 20 \text { to } 40 \mathrm{~min} \\
\text { (intervals of } 1 \mathrm{~min} \text { : } \\
2 \text { min) }\end{array}$ & $\begin{array}{l}\text { 50\% peak power and } \\
\text { at } 80 \% \text { of } 6 \mathrm{MWT} \text { average } \\
\text { speed } \\
\text { Duration: } 20 \text { to } 40 \mathrm{~min}\end{array}$ & $\begin{array}{l}3 \times \text { per week } \\
\text { for } 8 \text { weeks }\end{array}$ \\
\hline & $\begin{array}{l}\text { Nasis [56] } \\
n=42 \\
2009\end{array}$ & $\begin{array}{l}\text { Cycling in people } \\
\text { with COPD }\end{array}$ & $\begin{array}{l}\text { 100\% peak power and } \\
45 \% \text { peak power } \\
\text { Duration: } 30 \text { to } 40 \mathrm{~min} \\
\text { (intervals of } 30 \mathrm{~s} \text { ) }\end{array}$ & $\begin{array}{l}60 \% \text { peak power } \\
\text { Duration: } 30 \text { to } 40 \mathrm{~min}\end{array}$ & $\begin{array}{l}3 \times \text { per week } \\
\text { for } 10 \text { weeks }\end{array}$ \\
\hline & $\begin{array}{l}\text { a Puhan [57] } \\
n=98 \\
2006\end{array}$ & $\begin{array}{l}\text { Cycling in people } \\
\text { with COPD }\end{array}$ & $\begin{array}{l}50 \% \text { peak power of a } \\
\text { steep-ramp test, followed } \\
\text { by } 10 \% \text { peak power } \\
\text { Duration: } 25 \mathrm{~min} \\
\text { (intervals of } 20 \mathrm{~s} \text { : } \\
40 \mathrm{~s} \text { ) }\end{array}$ & $\begin{array}{l}\geq 70 \% \text { peak power } \\
\text { Duration: } 25 \mathrm{~min}\end{array}$ & $\begin{array}{l}5 \times \text { per week } \\
\text { for } 3 \text { weeks }\end{array}$ \\
\hline & $\begin{array}{l}\text { Varga [58] } \\
n=71 \\
2007\end{array}$ & $\begin{array}{l}\text { Cycling in people } \\
\text { with COPD }\end{array}$ & $\begin{array}{l}\text { 50\% peak power } \\
\text { interspersed with 10\% } \\
\text { peak power } \\
\text { Duration: } 45 \mathrm{~min} \\
\text { (intervals of } 20 \mathrm{~s} \text { : } \\
40 \mathrm{~s} \text { ) }\end{array}$ & $\begin{array}{l}\geq 70 \% \text { peak power } \\
\text { Duration: } 45 \mathrm{~min}\end{array}$ & $\begin{array}{l}3 \times \text { per week } \\
\text { for } 8 \text { weeks }\end{array}$ \\
\hline & $\begin{array}{l}\text { Vogiatzis [30] } \\
n=36 \\
2002\end{array}$ & $\begin{array}{l}\text { Cycling in people } \\
\text { with COPD }\end{array}$ & $\begin{array}{l}100 \% \text { peak power and } \\
45 \% \text { peak power (intervals } \\
\text { increased progressively to } \\
140 \% \text { peak power) } \\
\text { Duration: } 40 \text { min (intervals } \\
\text { of } 30 \text { s) }\end{array}$ & $\begin{array}{l}50 \% \text { peak power, increasing } \\
\text { to } 70 \% \text { by the end of the } \\
\text { program } \\
\text { Duration: } 40 \mathrm{~min}\end{array}$ & $\begin{array}{l}2 \times \text { per week } \\
\text { for } 12 \text { weeks }\end{array}$ \\
\hline & $\begin{array}{l}\text { Vogiatzis [59] } \\
n=19 \\
2005\end{array}$ & $\begin{array}{l}\text { Cycling in people } \\
\text { with COPD }\end{array}$ & $\begin{array}{l}100 \% \text { peak power and } 45 \% \\
\text { peak power, (intervals } \\
\text { increased progressively to } \\
140 \% \text { peak power) } \\
\text { Duration: } 45 \text { min (intervals } \\
\text { of } 30 \text { s) }\end{array}$ & $\begin{array}{l}60 \% \text { peak power, increasing } \\
\text { to } 70 \% \text { by the end of the } \\
\text { program } \\
\text { Duration: } 45 \mathrm{~min}\end{array}$ & $\begin{array}{l}3 \times \text { per week } \\
\text { for } 10 \text { weeks }\end{array}$ \\
\hline \multirow[t]{2}{*}{ Additional studies } & $\begin{array}{l}{ }^{\mathrm{a}} \text { BrØnstad [60] } \\
n=20 \\
2013\end{array}$ & $\begin{array}{l}\text { Uphill treadmill } \\
\text { walking in people } \\
\text { with COPD }\end{array}$ & $\begin{array}{l}\text { } 90 \% \text { maximal heart rate } \\
\text { ('work') } \\
\text { Duration: } 38 \mathrm{~min} \text { (intervals } \\
\text { of } 4 \mathrm{~min}: 4 \mathrm{~min} \text { ) }\end{array}$ & $\begin{array}{l}\text { 70\% maximum heart rate } \\
\text { Duration: } 47 \mathrm{~min}\end{array}$ & $\begin{array}{l}3 \times \text { per week } \\
\text { for } 10 \text { weeks }\end{array}$ \\
\hline & $\begin{array}{l}\text { Rodriguez }[61] \\
n=29 \\
2016\end{array}$ & $\begin{array}{l}\text { Cycling in people } \\
\text { with COPD }\end{array}$ & $\begin{array}{l}70 \text { to } 100 \% \mathrm{~W}_{\max } \text { (progressively } \\
\text { increased over the program), } \\
\text { interspersed with } 40 \text { to } 50 \% \\
W_{\max } \\
\text { Duration: } 40 \text { min (intervals of } \\
2 \text { min: } 3 \text { min) }\end{array}$ & $\begin{array}{l}60 \% \mathrm{~W}_{\max } \\
\text { Duration: } 40 \mathrm{~min}\end{array}$ & $\begin{array}{l}3 \times \text { per week } \\
\text { for } 8 \text { weeks }\end{array}$ \\
\hline
\end{tabular}

Abbreviations: $6 M W D$ six minute walk distance, $6 M W T$ six minute walk test, $\mathrm{Cl}$ confidence interval, $C O P D$ chronic obstructive pulmonary disease, $V O_{2 \text { peak }}$ peak rate of oxygen uptake, $W_{\text {max }}$ maximum work rate. ${ }^{a}$ identifies studies whereby the total work undertaken was unmatched between exercise training programs. The studies by Puhan et al. [57] and Varga et al. [58] report prescribing an intensity equivalent to 50\% peak power of a steep-ramp test. This protocol is known to produce much higher maximum work rates than the traditional incremental / ramp protocols. In both studies, the authors clarify that work rates equivalent to $50 \%$ of the maximum achieved on this test is the equivalent to 90\% of maximum work rate achieved during traditional protocols. Rodriguez at al [61] reported that during the first 2 weeks of the program, cycling at high work rate was set to a minimum of $70 \% \mathrm{~W}_{\text {max }}$ and was thereafter increased at $5 \%$ every week so that by week 3 , training was being undertaken at a sufficiently high intensity to be classified as 'HIIT' 


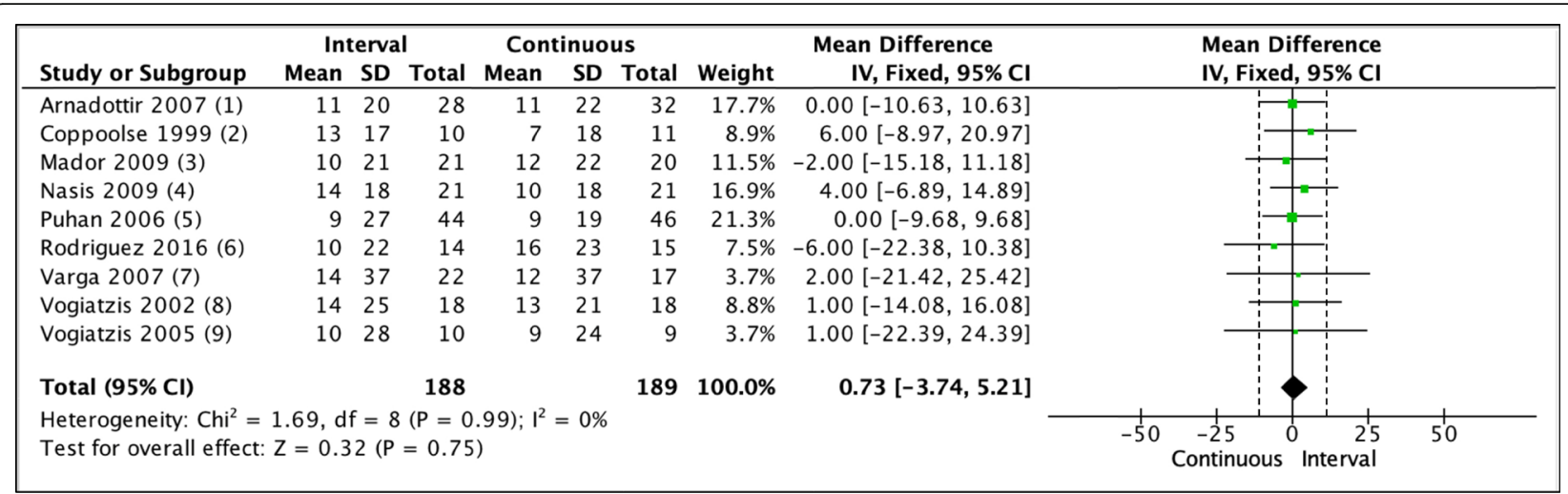

Footnotes:

(1) Within-group difference (Watts) and baseline SD

(2) Within-group difference (Watts) and baseline SD - paper reported within-group difference as a \% of baseline. Value in Watts was calculated by the review authors

(3) Within-group difference (Watts) and baseline SD

(4) Within-group difference (Watts) and baseline SD - paper reported SEM rather than SD. SD was calculated by the review authors

(5) Within-group difference (Watts) and baseline SD

(6) Within-group difference (Watts) and baseline SD - paper reported within-group difference as a \% of baseline. Value in Watts was calculated by the review authors

(7) Within-group difference (Watts) and baseline SD - paper reported within-group difference as a \% of baseline. Value in Watts was calculated by the review authors

(8) Within-group difference (Watts) and baseline SD - paper reported SEM rather than SD. SD was calculated by the review authors. Paper reported withingroup difference as a \% of baseline. Value in Watts was calculated by the review authors

(9) Within-group difference (Watts) and SD - paper reported SEM rather than SD. SD was calculated by the review authors

Note: Dashed line indicates the suggested minimal clinically important difference (MCID) for Watts ( 10W).

Fig. 1 Comparison of effect of HIIT versus continuous exercise training on maximal work rate (measured in Watts)

were matched for total volume of work. The HIIT and continuous exercise group improved their $\mathrm{W}_{\max }$ by $12 \%$ $(89 \pm 56 \mathrm{~W}$ to $108 \pm 60 \mathrm{~W})$ and $8 \%(93 \pm 49 \mathrm{~W}$ to $109 \pm$ $59 \mathrm{~W})$, respectively. However, although the magnitude of between group change was similar, the $95 \%$ confidence interval was wide and offered little precision (MD $1 \mathrm{~W}$, 95\% CI -51 to 49$)$. Similar results were reported for 6 minute walk distance (6MWD), with increases of $45 \mathrm{~m}$ $(538 \pm 70 \mathrm{~m}$ to $583 \pm 83 \mathrm{~m})$ and $48 \mathrm{~m}(516 \pm 57 \mathrm{~m}$ and $564 \pm 55 \mathrm{~m})$ in the HIIT and continuous groups,

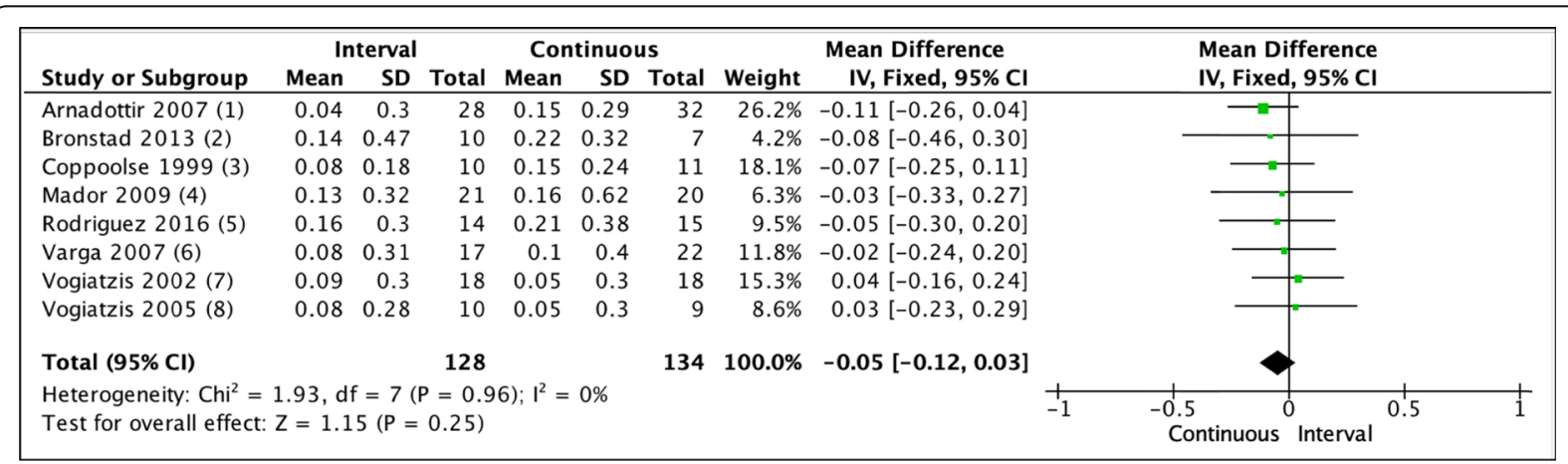

Footnotes:

(1) Within-group difference $\mathrm{L} \cdot \mathrm{min}^{-1}$ and baseline SD

(2) Within-group difference $\mathrm{L} \cdot \mathrm{min}^{-1}$ and baseline SD - paper reported within-group difference as a \% of baseline. Value in L.min ${ }^{-1}$ was calculated by the review authors

(3) Within-group difference $L \cdot \min ^{-1}$ and baseline SD

(4) Within-group difference $\mathrm{L} \cdot \mathrm{min}^{-1}$ and baseline SD - paper reported SEM rather than SD. SD was calculated by the review authors

(5) Within-group difference $\mathrm{L} \cdot \mathrm{min}^{-1}$ and baseline SD

(6) Within-group difference L. $\min ^{-1}$ and baseline SD - paper reported within-group difference as a $\%$ of baseline. Value in L.min ${ }^{-1}$ was calculated by the review authors

(7) Within-group difference L. $\mathrm{min}^{-1}$ and baseline SD - paper reported within-group difference as a \% of baseline. Value in L-min ${ }^{-1}$ was calculated by the review authors

(8) Within-group difference L. $\mathrm{min}^{-1}$ and baseline SD - paper reported SEM rather than SD. SD was calculated by the review authors. Paper reported within-group difference as a $\%$ of baseline. Value in $\mathrm{L} \cdot \mathrm{min}^{-1}$ was calculated by the review authors

(9) Within-group difference $\mathrm{L} \cdot \mathrm{min}^{-1}$ and SD - paper reported SEM rather than SD. SD was calculated by the review authors

Note: MCID not included as the value is unknown for $\mathrm{VO}_{2 \text { peak }}$ in COPD.

Fig. 2 Comparison of effect of HIIT versus continuous exercise training on peak oxygen uptake (measured in L/min) 
Table 2 High intensity interval training in adults with cystic fibrosis

\begin{tabular}{|c|c|c|c|c|}
\hline Study & Population & Interval exercise & Continuous exercise & Frequency and duration \\
\hline $\begin{array}{l}\text { Gruber [38] } \\
n=23 \\
2014\end{array}$ & $\begin{array}{l}\text { Adults (medically } \\
\text { stable inpatients) }\end{array}$ & $\begin{array}{l}\text { 1: } 2 \text { work recovery } \\
\text { ratio ( } 30 \mathrm{~s}: 60 \mathrm{~s}, 20 \mathrm{~s} \text { : } \\
60 \mathrm{~s} \text { if more } \\
\text { deconditioned) on a } \\
\text { treadmill. Speed } 3 \text { to } \\
4 \mathrm{~km} / \mathrm{hr} \text {. (work) and } \\
50 \% \text { incline, } 0 \% \text { incline } \\
\text { (active recovery) } \\
\text { Duration: } 16 \text { min (10 } \\
\text { interval bouts) }\end{array}$ & $\begin{array}{l}\text { Various sport activities } \\
\text { depending on fitness } \\
\text { level (i.e. walking, ball } \\
\text { games, stretching, } \\
\text { balance training and } \\
\text { resistance training). } \\
\text { HR corresponding } \\
80-90 \% \text { equivalent to } \\
60 \text { to } 75 \% \mathrm{VO}_{2 \text { peak }} \\
\text { (unmatched workload } \\
\text { between groups) } \\
\text { Duration: } 45 \mathrm{~min}\end{array}$ & 5 times $\times$ week for 6 weeks \\
\hline $\begin{array}{l}\text { Kaltsakas [65] } \\
n=24 \\
2017\end{array}$ & Adults & $\begin{array}{l}30 \mathrm{~s} 100 \% \mathrm{~W}_{\max } \\
\text { interspersed with } \\
40 \% \mathrm{~W}_{\max } \text { for } 30 \mathrm{~s} \\
\text { Duration: } 30 \mathrm{~min}\end{array}$ & $\begin{array}{l}70 \% \mathrm{~W}_{\max } \\
\text { (matched workload } \\
\text { between groups) } \\
\text { Duration: } 30 \mathrm{~min}\end{array}$ & $\begin{array}{l}12 \text { weeks (frequency per } \\
\text { week not provided) }\end{array}$ \\
\hline
\end{tabular}

Abbreviations: $\mathrm{Cl}$ confidence interval, $H R$ heart rate, $W_{\max }$ maximal work rate

respectively (MD $19 \mathrm{~m}, 95 \% \mathrm{CI}-41$ to 79 ) [58]. Despite being matched for the total volume of work undertaken, during the training program, when compared with the continuous group, the HIIT reported lower peak dyspnoea scores ( $4 \pm 1$ vs $6 \pm 1$ [MD 2, 95\% CI -3 to -1 ]) and higher nadir oxygen saturation $\left[\mathrm{SpO}_{2}\right](94 \pm 1 \%$ versus $91 \pm 1 \%$, [MD 3, 95\% CI 2 to 4$]$ ). This suggests that HIIT may be a more tolerable mode of exercise training in adults with CF.

\section{Non-cystic fibrosis bronchiectasis}

There appears to be no published studies that have investigated the effects of HIIT in people with non-CF bronchiectasis.

\section{Asthma}

Although one of the first uncontrolled studies investigating high intensity exercise in people with asthma was undertaken in 1996 [66], to date, only one RCT has evaluated the effect of HIIT compared to usual care (i.e. no exercise) on exercise capacity in this population [67]. In this RCT, untrained people with asthma were allocated to undertake an 8 week intervention period consisting of thrice weekly HIIT ( $n=20$, aged $39 \pm 13$ years; $\mathrm{FEV}_{1} /$ FVC $0.91 \pm 0.01$ ) on a cycle ergometer, compared with a usual care group (i.e. no formal exercise training) $(n=$ 34 , aged $38 \pm 13$ years, $\mathrm{FEV}_{1} / \mathrm{FVC} 0.85 \pm 0.01$ ). For participants allocated to receive the HIIT, each session comprised a 10 min warm up at a low intensity, followed by consecutive 1 minute exercise bouts for a 5 minute period. The intensity achieved during each minute of exercise was dynamic, with a relative rest and high intensity exercise integrated into each minute bout. That is, the first $30 \mathrm{~s}$ was undertaken at $<30 \%$ of the maximal heart rate (relative 'rest'), the second $20 \mathrm{~s}$ was undertaken at $<60 \%$ of the maximal heart rate, and the final $10 \mathrm{~s}$ was undertaken at $>90 \%$ of the maximal heart rate (high intensity). The 5 minute sets were repeated twice in the first 2 weeks, and progressively increased up to four sets throughout the intervention period. Each training session concluded with a $10 \mathrm{~min}$ cool down. This type of HIIT intervention was reported to be well tolerated and elicited an increase in $\mathrm{VO}_{2 \text { peak }}$ that was over and above any change in the usual care group (between group difference in $\mathrm{VO}_{2 \text { peak }} 3 \pm 4 \mathrm{~mL} / \mathrm{kg} / \mathrm{min} ; p<0.0001$ ) $[67,68]$. However, the authors speculate that achieving a heart rate of $>90 \%$ of the maximal heart rate within a $10 \mathrm{~s}$ period may be difficult to replicate in clinical practice. In addition to the effects of HIIT compared to usual care, one RCT (results reported in a conference abstract; $n=16$ in the HIIT group, no data on age or pulmonary function) demonstrated that HIIT offered comparable benefits to moderate intensity continuous exercise, albeit with lower overall symptoms of dyspnoea [69]. In this study, the HIIT group undertook $30 \mathrm{~s}$ work bouts at 80 to $140 \%$ of the $\mathrm{W}_{\max }$. This training regimen was compared with continuous exercise at 70 to $85 \%$ of the maximal heart rate. Similar improvements in $\mathrm{VO}_{2 \text { peak }}$ were demonstrated following both modes of exercise (unable to calculate $95 \%$ CI from data provided). In addition, dyspnoea was lower during HIIT compared to continuous exercise $(p<0.05$, unable to calculate $95 \% \mathrm{CI}$ from data provided).

Nevertheless, one contentious issue regarding HIIT for people with asthma is whether or not it is more or less likely to induce exercise-induced bronchoconstriction. Specifically, some, but not all studies [69] have reported more modest decreases in $\mathrm{FEV}_{1}$ in response to HIIT (90\% $\mathrm{W}_{\max }$ for 1 minute followed by $10 \%$ of $\mathrm{W}_{\max }$ for 1 minute, repeated 10 times; $\mathrm{FEV}_{1}-7 \% \pm 8 \%$ ) when compared with moderate intensity continuous training programs (completed at $65 \% \mathrm{~W}_{\text {max }} ; \mathrm{FEV}_{1}-15 \% \pm 12 \%$ ) [40, 70]. Similarly, the effects of HIIT compared with continuous training approaches on dyspnoea and rating of 
perceived exertion experienced during training are also disparate [71, 72]. Studies which included a warm-up period, rather than commencing with work intervals by cycling 'as fast as possible' without any resistance on the pedals appeared to induce less bronchoconstriction [70]. When applying HIIT, clinicians should consider offering a warm-up period and monitor $\mathrm{FEV}_{1}$ and symptoms for evidence of exercise-induced bronchoconstriction.

\section{Interstitial lung diseases}

Despite the recognised benefit of exercise training for people with ILDs [28, 73-76], there are currently no published studies evaluating the effects of HIIT, compared to usual care or continuous exercise, in people with these conditions. A group of researchers from Melbourne, Australia are currently undertaking an RCT in this field (ACTRN12619000019101). A recent conference abstract reported data collected in a small group of people with ILD $(n=6$, age and forced vital capacity [FVC] not reported) [77] showing comparable levels of dyspnoea and leg muscle fatigue during HIIT (100\% $\mathrm{W}_{\max }$ for $30 \mathrm{~s}$ interspersed with $30 \mathrm{~s}$ of unloaded cycling; modified Borg $4 \pm 2$ and Borg $13 \pm 4$, respectively) and moderate intensity continuous exercise $\left(60 \% \mathrm{~W}_{\max }\right.$; modified Borg $3 \pm 1$ and Borg $13 \pm 5$, respectively). Similarly, HIIT was undertaken with comparable exercise heart rates and nadir $\mathrm{SpO}_{2}$, despite a higher overall training work load for the HIIT compared to moderate intensity continuous exercise [77].

\section{Lung cancer}

A couple of studies have reported the feasibility and safety of incorporating a component of HIIT in exercise training interventions for people with NSCLC [78, 79]. One RCT compared the effects of short-term HIIT (median [IQR] number of sessions $=8$ [7 to 10] in 26 [21 to 33] days) with usual care in people with NSCLC, prior to lung resection surgery [80]. Participants allocated to receive HIIT ( $n=74$, aged $64 \pm 13$ years, $\mathrm{FEV}_{1} 86 \pm 22 \%$ predicted) were asked to attend three supervised exercise sessions per week (variable length of program according to date of surgery). The HIIT comprised a 5 minute warm-up $\left(50 \% \mathrm{~W}_{\max }\right)$, following by a $10 \mathrm{~min}$ bout of $15 \mathrm{~s}$ sprints (80 to $100 \% \mathrm{~W}_{\max }$ ) interspersed with $15 \mathrm{~s}$ of low intensity exercise $\left(30 \% \mathrm{~W}_{\max }\right)$. This HIIT set was separated by a 4 minute rest, and then repeated (i.e. two 10 min sets were completed per training session). Compared with a control group that received no formal exercise training ( $n=77$, aged $64 \pm 10$ years, $\mathrm{FEV}_{1} 88 \pm 19 \%$ predicted), the HIIT group demonstrated greater improvements in $\mathrm{VO}_{2 \text { peak }}$ on completion of the training program (MD $4 \mathrm{~mL} / \mathrm{kg} / \mathrm{min}, 95 \%$ CI 2 to 6) [80]. Studies comparing the effects of HIIT with moderate intensity continuous exercise in people with this condition are lacking.

\section{Conclusions}

In people with COPD, when compared with no training, HIIT produces gains in cardiorespiratory fitness and exercise capacity. The magnitude of these gains appears to be similar to those achieved with continuous exercise. In people with $\mathrm{CF}$, non-CF bronchiectasis and ILDs, there are currently no RCTs evaluating the effects of HIIT compared to usual care or to moderate intensity continuous exercise. Nevertheless, in people with CF and ILDs, there are data to show that HIIT is well-tolerated. High intensity interval training in people with asthma is somewhat contentious, owing to the variable effects on bronchoconstriction and symptoms during exercise. Data from one RCT [80] supports the use of preoperative HIIT (compared to usual care) in people with NSCLC to increase exercise capacity. However, the effects of HIIT compared with moderate intensity continuous exercise in people with NSCLC are unknown.

Some studies (particularly those with the shorter intervals) have shown superior improvement in exercise capacity (workload) with comparable improvements in cardiorespiratory fitness $\left(\mathrm{VO}_{2 \text { peak }}\right)$ favouring HIIT [53$55,60,61]$. Additionally, $70 \%$ of studies included within this narrative review prescribe interventions whereby the total volume of work was matched between the HIIT and continuous exercise interventions. That is, the overall training load borne was equivalent between the HIIT and continuous exercise, which is likely to explain why similar effects were demonstrated between the two modes of exercise training in most studies. As such, future studies, particularly in COPD, are needed to determine whether HIIT, during which a smaller total training load is prescribed is able to produce comparable or superior benefits in exercise capacity and cardiorespiratory fitness to continuous exercise. This review emphasises the need for large RCTs investigating the effects of HIIT compared to usual care and HIIT compared to moderate intensity continuous exercise in most chronic pulmonary disease populations.

\section{Abbreviations}

6MWD: Six minute walk distance; 6MWT: Six minute walk test; CF: Cystic fibrosis; Cl: Confidence interval; COPD: Chronic obstructive pulmonary disease; CS: Citrate synthase; $\mathrm{FEV}_{1}$ : Forced expiratory volume in $1 \mathrm{~s}$; FVC: Forced vital capacity; HADH: 3-hydroxyacyl-CoA dehydrogenase; HIIT: High intensity interval training; HR: Heart rate; ILD: Interstitial lung disease; IPF: Idiopathic pulmonary fibrosis; IQR: Interquartile range; MCID: Minimal clinically importance difference; MD: Mean difference; NSCLC: Non-small cell lung cancer; RCT: Randomised controlled trial; SD: Standard deviation; SEM: Standard error of the mean; $\mathrm{VO}_{2 \text { peak: }}$ Peak rate of oxygen uptake; $W_{\text {max }}$ : Maximal work rate 


\section{Authors' contributions}

$\mathrm{AS}, \mathrm{KH}$ and $\mathrm{VC}$ all contributed to the writing and editing of this review article. The author(s) read and approved the final manuscript.

\section{Availability of data and materials}

Upon request from authors.

\section{Ethics approval and consent to participate}

Not applicable (review article).

\section{Consent for publication}

Yes.

\section{Competing interests}

The authors declare that they have no competing interests.

\section{Author details}

${ }^{1}$ School of Physiotherapy and Exercise Science, Faculty of Health Science, Curtin University, GPO Box U1987, Perth, WA 6845, Australia. ${ }^{2}$ Physiotherapy Department, Sir Charles Gairdner Hospital, Perth, WA, Australia. Institute for Respiratory Health, Perth, WA, Australia. ${ }^{4}$ Allied Health, South Metropolitan Health Service, Perth, Australia.

\section{Received: 13 October 2019 Accepted: 28 February 2020}

\section{Published online: 30 March 2020}

\section{References}

1. McCarthy B, Casey D, Devane D, Murphy K, Lacasse Y. Pulmonary rehabilitation for chronic obstructive pulmonary disease. Cochrane Database Syst Rev. 2015;23(2):CD003793.

2. Rabe KF, Hurd S, Anzueto A, Barnes PJ, Buist SA, Calverley P, Fukuchi Y, Jenkins C, Rodriguez-Roisin R, van Weel C, Zielinski J. Global strategy for the diagnosis, management, and prevention of chronic obstructive pulmonary disease: GOLD executive summary. Am J Respir Crit Care Med. 2007;176(6): 532-55

3. Radtke T, Nolan SJ, Hebestreit H, Kriemler S. Physical exercise training for cystic fibrosis. PaedResp Rev. 2016;19:42-5.

4. Button BM, Wilson C, Dentice R, Cox NS, Middleton A, Tannenbaum E, Bishop J, Cobb R, Burton K, Wood M. Physiotherapy for cystic fibrosis in Australia and New Zealand: a clinical practice guideline. Respirology. 2016; 21(4):656-67.

5. Holland A, Hill C. Physical training for interstitial lung disease. Cochrane Database Syst Rev. 2008:4:CD006322.

6. Curtis K, Hopkinson NS. Exercise training in interstitial lung disease: lumping or splitting? Thorax. 2017:72(7):589-90.

7. Nakazawa A, Cox NS, Holland AE. Current best practice in rehabilitation in interstitial lung disease. Ther Adv Respir Dis. 2017:11(2):115-28.

8. Carson KV, Chandratilleke MG, Picot J, Brin MP, Esterman AJ, Smith BJ. Physical training for asthma. Cochrane Database Syst Rev. 2013:9:CD001116.

9. Cavalheri V, Tahirah F, Nonoyama M, Jenkin S, Hill K. Exercise training undertaken by people within 12 months of lung resection for non-small cell lung cancer. Cochrane Database Syst Rev. 2019;6:1-50.

10. Peddle-McIntyre CJ, Singh F, Thomas R, Newton RU, Galvae DA, Cavalheri V. Exercise training for advanced lung cancer. Cochrane Database Syst Rev. 2019;2:1-48

11. Cavalheri V, Granger C. Preoperative exercise training for patients with nonsmall cell lung cancer. Cochrane Database Syst Rev. 2017;6:CD012020.

12. Lee AL, Hill CJ, Cecins N, Jenkins S, McDonald CF, Burge AT, Rautela L Stirling RG, Thompson PJ, Holland AE. The short and long term effects of exercise training in non-cystic fibrosis bronchiectasis - a randomised controlled trial. Respir Res. 2014;15(1):44.

13. Garber CE, Blissmer B, Deschenes MR, Franklin BA, Lamonte MJ, Lee IM, et al. Quantity and quality of exercise for developing and maintaining cardiorespiratory, musculoskeletal, and neuromotor fitness in apparently healthy adults: guidance for prescribing exercise. Med Sci Sports Exerc. 2011:43(7):1334-59. https://doi.org/10.1249/MSS.0b013e318213fefb.

14. Casaburi R, Porszasz J, Burns MR, Carithers ER, Chang RS, Cooper CB. Physiologic benefits of exercise training in rehabilitation of patients with severe chronic obstructive pulmonary disease. Am J Respir Crit Care Med. 1997;155(5):1541-51
15. Casaburi R, ZuWallack R. Pulmonary rehabilitation for management of chronic obstructive pulmonary disease. N Engl J Med. 2009;360(13):1329-35.

16. Troosters T, Casabrui R, Gosselink R, Decramer M. Pulmonary rehabilitation in chronic obstructive pulmonary disease. Am J Respir Crit Care Med. 2005: 172(1):19-38.

17. Casaburi R, Patessio A, Ioli F, Zanaboni S, Donner CF, Wasserman K. Reductions in exercise lactic acidosis and ventilation as a result of exercise training in patients with obstructive lung disease. Am Rev Respir Med. 1991. 143(1):9-18.

18. Morris NR, Walsh J, Adams L, Alision J. Exercise training in COPD: what is it about intensity? Respirology. 2016;21(7):1185-92.

19. McArdle WD, Katch FI, Katch VL. Essentials of exercise physiology. Baltimore: Lippincott Williams \& Wilkins; 2006

20. Pianosi P, Leblanc J, Almudevar A. Peak oxygen uptake and mortality in children with cystic fibrosis. Thorax. 2005:60(1):50-4.

21. Nixon PA, Orenstein DM, Kelsey SF, Doershuk CF. The prognostic value of exercise testing in patients with cystic fibrosis. N Engl J Med. 1992:327(25):1785-8.

22. Camillo CA, Langer D, Osadnik CR, Pancini L, Demeyer H, Burtin C, Gosselink $\mathrm{R}$, Decramer $\mathrm{M}$, Janssens $\mathrm{W}$, Troosters $\mathrm{T}$. Survival after pulmonary rehabilitation in patients with COPD: impact of functional exercise capacity and its changes. Int J Chron Obstruct Pulmon Dis. 2016;11:2671-9.

23. Ries AL, Kaplan RM, Limberg TM, Preqitt LM. Effects of pulmonary rehabilitation on physiologic and psychosocial outcomes in patients with chronic obstructive pulmonary disease. Ann Intern Med. 1995;122(11):823-32.

24. Maltais F, LeBlanc P, Simard C, Jobin J, Berube C, Bruneau J, Carrier L, Beleau R. Skeletal muscle adaptation to endurance training in patients with chronic obstructive pulmonary disease. Am J Respir Crit Care Med. 1996;154(2):442-7.

25. Szucs B, Petrekanits M, Varga J. Effectiveness of a 4-week rehabilitation program on endothelial function, blood vessel elasticity in patients with chronic obstructive pulmonary disease. J Thorac Dis. 2018:10(12):6482-90.

26. Gelinas JC, Lewis NC, Harper MI, Melzer B, Agar G, Rolf JD, Eves ND. Aerobic exercise training does not alter vascular structure and function in chronic obstructive pulmonary disease. Exp Physiol. 2017;102(11):1548-60.

27. Vivodtzev I, Minet C, Wuyam B, Borel JC, Vottero G, Monneret D, Baguet JP, Levy P, Pepin JL. Significant improvement in arterial stiffness after endurance training in patients with COPD. Chest. 2010:137(3):585-92.

28. Dowman L, Hill CJ, Holland AE. Pulmonary rehabilitation for interstitial lung disease. Cochrane Database Syst Rev. 2014;10:CD006322.

29. Lee AL, Hill CJ, McDonald CF, Holland AE. Pulmonary rehabilitation in individuals with non-cystic fibrosis bronchiectasis: a systematic review. Arch Phys Med Rehabil. 2017;98(4):774-82.

30. Vogiatzis I, Nanas S, Roussos C. Interval training as an alternative modality to continuous exercise in patients with COPD. Eur Respir J. 2002;20(1):12-9.

31. Vogiatzis I, Zakynthinos S. Factors limiting exercise tolerance in chronic lung diseases. Compr Physiol. 2012;2(3):1779-817.

32. Alison JA, McKeough ZJ, Leung RWM, Holland AE, Hill K, Morris NR, Jenkins S, Spencer LM, Hill CJ, Lee AL, Seale H, Cecins N, McDonald CF. Oxygen compared to air during exercise training in COPD with exercise-induced desaturation. Eur Respir J. 2019:54(5):1802429.

33. Bell EC, Cox NC, Nicole G, Glaspole I, Westall GP, Watson A, Holland AE. Supplemental oxygen and dypsnoea in interstitial lung disease: absence of evidence is not evidence of absence. Eur Respir Rev. 2017;26(145):170072.

34. Johannson KA, Pendharkar SR, Mathison K, Fell CD, Guenette JA, Kalluri M Kolb M, Ryerson CJ. Supplemental oxygen in interstitial lung disease: an art in need of science. Ann Am Thorac Soc. 2017:14(9):1373-7.

35. Wshah A, Guilcher SJ, Goldstein R, Brooks D. Prevalence of osteoarthritis in individuals with COPD: a systematic review. Int J Chron Obstruct Pulmon Dis. 2018;13:1207-16.

36. Eisner MD, Blanc PD, Yelin YH, Katz PP, Sanchez G, Iribarren C, Omachi TA. Influence of anxiety on health outcomes in COPD. Thorax. 2010; 65(3):229-34

37. Westermann $\mathrm{H}$, Choi TN, Briggs WM, CHarlson ME, Mancuso CA. Obesity and exercise habits of asthmatic patients. Ann Allergy Asthma Immunol. 2008:101(5):488-94.

38. Gruber W, Orenstein DM, Braumann KM, Beneke R. Interval exercise training in cystic fibrosis- effects on exercise capacity in severely affected adults. J Cyst Fibros. 2014;13(1):86-91

39. Beauchamp MK, Nonoyama M, Goldstein RS, Hill K, Dolmage TE, Mathur $\mathrm{S}$, Brooks D. Interval versus continuous training in individuals with chronic obstructive pulmonary disease- a systematic review. Thorax. 2010;65(2):157-64. 
40. O'Neill C, Burgomaster K, Sanchez O, Dogra S. The acute response to interval and continuous exercise in adults with confirmed airway hyperresponsiveness. J Sci Med Sport. 2017;20(11):976-80.

41. Billat LV. Interval training for performance: a scientific and empirical practice. Special recommendations for middle- and long-distance running. Part I: aerobic interval training. Sports Med. 2001;31(1):13-31.

42. Laursen PB. Training for intense exercise performance: high-intensity or high-volume training? Scand J Med Sci Sports. 2010;20(Suppl 2):1-10.

43. Porszasz J, Rambod M, Hester V, Casaburi R. Sinusoidal high-intensity exercise does not elicit ventilatory limitation in chronic obstructive pulmonary disease. Exp Physiol. 2013;98(6):1102-14.

44. Gibala MJ, Little J, MacDonald MJ, Hawley JA. Physiological adaptations to low-volume, high-intensity interval training in health and disease. J Physiol. 2012;590(5):1077-84

45. Burgomaster KA, Hughes SC, Heigenhauser GJ, Bradwell SN, Gibala MJ. Six sessions of sprint interval training increases muscle oxidative potential and cycle endurance capacity in humans. J Appl Physiol. 2005;98(6):1985-90.

46. Gillen JB, Martin BJ, Maclnnis MJ, Skelly LE, Tarnopolsky MA, Gibala MJ. Twelve weeks of sprint interval training improves indices of cardiometabolic health similar to traditional endurance training despite a five-fold lower exercise volume and time commitment. PLoS One. 2016;11(4):1-10.

47. Sawyer A, Cavalheri V, Wood J, Hill K. Exercise testing and exercise training within cystic fibrosis centres across Australia and New Zealand: what is considered important and what is current practice? Int Med J. 2019; [e-pub ahead of print].

48. Perez-Bogerd S, et al. Short and long-term effects of pulmonary rehabilitation in interstitial lung diseases: a randomised controlled trial. Respir Res. 2018;19(1):182.

49. Vainshelboim B, et al. Exercise training-based pulmonary rehabilitation program is clinically beneficial for idiopathic pulmonary fibrosis. Respiration. 2014:88(5):378-88.

50. Roitman JL. ACSM's guidelines for exercise testing and prescription. 9th ed. Baltimore: Lippincott Williams \& Wilkins; 2013. p. 472-9.

51. Alcazar J, Losa-Reyna J, Rodriguez Lopez C, Navarro-Cruz R, Alfaro-Acha A, Ignacio A, Garcia-Garcia RJ, Alegre LM, Guadalupe-Grau A. Effects of concurrent exercise training on muscle dysfunction and systemic oxidative stress in older people with COPD. Scand J Med Sci Sports. 2019;29:1591-1603.

52. Louvaris Z, Spetsioti S, Kortianou EA, Vasilopoulou M, Nasis I, Kaltsakas G, Vogiatzis I. Interval training induces clinically meaningful effects in daily activity levels in COPD. Eur Respir J. 2016:48(2):567-70.

53. Arnardóttir RH, Boman G, Larsson K, Hedenstrom H, Emtner M. Interva training compared with continuous training in patients with COPD. Respir Med. 2007;101(6):1196-204.

54. Coppoolse R, Schols AM, Baarends EM, Mostert R, Akkermans MA, Janssen $\mathrm{PP}$, Wouters EF. Interval versus continuous training in patients with severe COPD: a randomized clinical trial. Eur Respir J. 1999;14(2):258-63.

55. Mador MJ, Krawza M, Alhajhusian A, Khan Al, Shaffer M, Kufel TJ. Interval training versus continuous training in patients with chronic obstructive pulmonary disease. J Cardiopulm Rehabil Prev. 2009;29(2):126-32.

56. Nasis I, Vogiatzis I, Stratakos G, Athanasopoulos D, Koutsoukou A, Daskalakis A, Spetsioti S, Evangelodimou A, Roussos C, Zakynthinos S. Effects of interval-load versus constant-load training on the BODE index in COPD patients. Respir Med. 2009;103:1392-8.

57. Puhan MA, Busching G, Schunermann HJ, Zaugg C, Frey M. Interval versus continuous high-intensity exercise in chronic obstructive pulmonary disease: a randomized trial. Ann Intern Med. 2006;145(11):816-25.

58. Varga J, Porszasz J, Boda K, Casaburi R, Somfay A. Supervised high intensity continuous and interval training vs. self-paced training in COPD. Respir Med. 2007;101(11):2297-304

59. Vogiatzis I, Terzis G, Nanas S, Stratakos G, Simoes DC, Georgiadou O, Zakynthinos $S$, Roussos C. Skeletal muscle adaptations to interval training in patients with advanced COPD. Chest. 2005;128(6):3838-45.

60. Brønstad E, Tjonna AE, Rognmo O, Dalen H, Heggli AM, Wisloff U, Ingul CB, Steinshamn S. Aerobic exercise training improves right- and left ventricular systolic function in patients with COPD. J Chron Obstr Pulm Dis. 2013;10(3):300-6.

61. Rodriguez DA, Arbillaga A, Barberan-Garcia A, Ramirez-Sarmiento A, Torralba Y, Vilaro J, Gimeno-Santos E, Gea J, Orozco-Levi M, Roca J, Marco E. Effects of interval and continuous exercise training on autonomic cardiac function in COPD patients. Clin Respir J. 2016;10(1):83-9.

62. Elkins MR, Dwyer TJ. Interval and continuous training are similarly effective in chronic obstructive pulmonary disease. BJ Sports Med. 2011;45:155-6.
63. Hulzebos HJ, Snieder H, van der Et J, Helders PJ, Takken T. High-intensity interval training in an adolescent with cystic fibrosis: a physiological perspective. Physiother Theory Pract. 2011;27(3):231-7.

64. DiMenna FRR, Gunaratnam C, Arad AD, McElvaney GN. High-intensity interval training accelerates oxygen uptake kinetics and improves exercise tolerance for individuals with cystic fibrosis - a pilot study. Currently under review. 2019.

65. Kaltsakas G, Anastasopoulos N, Chynkiamis N, Zeliou P, Karapatoucha V, Kotsifas K, Diamantea F, Inglezos I, Koulouris NG, Vogiatzis I. S81 Functional capacity, peripheral muscle strength, and quality of life following interval versus continuous rehabilitative exercise training in cystic fibrosis. Thorax. 2017;72:A51.1-A51.

66. Emtner MM, Herala M, Stålenheim G. High-intensity physical training in adults with asthma: a 10-week rehabilitation program. Chest. 1996;109(2): 323-30.

67. Toennesen LL, Meier N, Hostrup M, Porsbjerg C, Backer V. High-intensity interval training improves maximal oxygen consumption in untrained adult asthmatics. ATS. 2016;A69:A2304.

68. Toennesen LL, Meier N, Hostrup M, Porsbjerg C, Backer V. Feasibility of highintensity training in asthma. Eur Clin Respir J. 2018:5(1):1468714.

69. Aparecido da Silva $R$, et al. High intensity interval training increases the clinical control, aerobic fitness and decreases dyspnea in severe asthmatics. Eur Respir J. 2016;48(suppl 60):PA1560.

70. Good J, Viana E, Burgomaster KA, Dogra S. Acute responses to sprintinterval and continuous exercise in adults with and without exerciseinduced bronchoconstriction. J Sports Sci. 2019;37(2):212-20.

71. Freeman A, Geale R, Bali S, Gove K, Cellura D, Burke H, Wallis T, Paas KHW, Staples KJ, Jack S, Grocott MPW, Wilkinson TMA. High intensity intermittent exercise training in poorly controlled asthma: preliminary clinical trial results. Thorax. 2018;73(Supp 4):A159-9.

72. Good J, Dogra S. Subjective responses to sprint interval exercise in adults with and without exercise-induced bronchoconstriction. J Asthma. 2018; 55(10):1059-67.

73. Vainshelboim B. Exercise training in idiopathic pulmonary fibrosis: is it of benefit? Breathe. 2016;12(2):130-8.

74. Bajwah S, Colquitt J, Loveman E, Bausemwein C, Almond H, Oluyase A, Wells A. Interventions to improve symptoms and quality of life of patients with fibrotic interstitial lung disease: a systematic review of the literature. Eur Respir J. 2013;68(9):867-79.

75. Wells AU, Hirani N. Interstitial lung disease guideline. Thorax. 2008;63(Suppl 5): $11-v 58$.

76. Spruit MA, Singh S, Garvey C, ZuWallack R, Nici L, Rochester C, Hill K, Holland AE, et al. An official American Thoracic Society/European Respiratory Society statement: key concepts and advances in pulmonary rehabilitation. Am J Respir Crit Care Med. 2013;188(8):13-64.

77. Dowman L, Cox N, Morris N, Nakazawa A, Bondarenko J, Parker L, Prasad J, Glaspole I, Holland AE. Acute physiological responses to interval and continuous training in ILD. Thoracic Society of Austrlia and New Zealand Annual Scientific Meeting. Gold Coast: Wiley; 2019.

78. Jones LW, Eves ND, Peterson BL, Garst J, Crawford J, West MJ, Mabe S, Harpole D, Kraus WE, Douglas PS. Safety and feasibility of aerobic training on cardiopulmonary function and quality of life in postsurgical nonsmall cell lung cancer patients. Cancer. 2008;113(12):3430-9.

79. Jones LW, Peddle CJ, Eves ND, Haykowsky MJ, Courneya KS, Mackey JR, Joy AA, Kumar V, Winton TW, Reiman T. Effects of presurgical exercise training on cardiorespiratory fitness among patients undergoing thoracic surgery for malignant lung lesions. Cancer. 2007;110(3):590-8.

80. Licker M, Karenovics W, Diaper J, Fresard I, Triponez F, Ellenberger C, Schorer R, Kayser B, Bridevaux PO. Short-term preoperative high-intensity interval training in patients awaiting lung cancer surgery: a randomized controlled trial. J Thorac Oncol. 2017;12(2):323-33.

81. Make B, Casaburi R, Leidy NK. Interpreting results from clinical trials: understanding minimal clinically important differences in COPD outcomes. COPD: J Chron Obstru Pulm Dis. 2005:2(1):1-5.

\section{Publisher's Note}

Springer Nature remains neutral with regard to jurisdictional claims in published maps and institutional affiliations. 